\title{
Immunoblotting detection of so-called 'antikeratin antibodies': a new assay for the diagnosis of rheumatoid arthritis
}

Véronique Gomès-Daudrix, Mireille Sebbag, Elisabeth Girbal, Christian Vincent, Michel Simon, Joël Rakotoarivony, Michel Abbal, Bernard Fournié, Guy Serre

\begin{abstract}
Objectives-To assess the diagnostic value for rheumatoid arthritis (RA), of an immunoblotting assay based on the rat oesophagus epithelium antigens recognised by the so-called 'antikeratin antibodies' ('AKA'), antigens that have been identified as three non-cytokeratin proteins (referred to as $A, B$ and $C$ proteins). Methods-After polyacrylamide gel electrophoresis in non-denaturing conditions and electrotransfer of an epithelial extract, the immunoreactivities to the $A, B$ and $C$ proteins of a series of serum samples from 88 patients with $R A$ and 100 patients with non-rheumatoid rheumatic diseases, were semiquantitatively evaluated.
\end{abstract}

Results-A total of $81.8 \%$ of $R A$ serum samples recognised the three proteins, while $91 \%$ of non-RA serum samples only weakly recognised the $A$ and $B$ proteins but not the $C$ protein. Only in the group of RA patients, were the titres of the antibodies to the $A, B$ and $C$ proteins found to be significantly correlated with each other and with the titres of 'AKA' detected by the standard indirect immunofluorescence (IIF) method. For a diagnostic specificity of $99 \%$, the diagnostic sensitivities of the detection of the $A$ and $B$ proteins were $50 \%$ and $43.2 \%$, respectively, when those of the detection of 'AKA' by IIF and of IgM-rheumatoid factor by enzyme-linked immunosorbent assay were $42 \%$ and $54 \%$, respectively. In contrast, at a same specificity of $99 \%$, the diagnostic sensitivity of the detection of the $\mathbf{C}$ protein was significantly higher with a value of $70 \cdot 5 \%$.

Conclusion-This immunoblotting assay which is the first immunochemical method proposed for the detection of 'AKA', should be validated on larger series of patients but can already be considered as a very powerful test for the serological diagnosis of RA.

(Ann Rheum Dis 1994; 53: 735-742)

A wide variety of circulating autoantibodies are found in most patients with rheumatoid arthritis (RA). ${ }^{1-15}$ Among these antibodies, the rheumatoid factor (RF), mainly of the $M$ isotype, is considered to be characteristic of the disease. Thus it is currently used in the diagnosis of $\mathrm{RA}^{1-3} 10$ and constitutes one of the classification criteria proposed by the American Rheumatism Association. ${ }^{16}$ However, based on the methods commonly used for its detection (latex and Waaler-Rose tests) and the threshold titres generally considered as significant, this autoantibody shows a low diagnostic specificity. It is found in patients with various other autoimmune rheumatic diseases, and even in a noticeable proportion of normal healthy subjects. ${ }^{17}$

Since the first study by Young et $a l,{ }^{18}$ numerous authors ${ }^{19-32}$ have described in RA, serum IgG antibodies labelling the stratum corneum of rat oesophagus epithelium. It is now largely accepted that their presence constitutes the most specific serological criterion for the diagnosis of RA. ${ }^{19} 21^{22}{ }^{24-33} \mathrm{By}$ the standard indirect immunofluorescence (IIF) method associated with an original semiquantitative estimation of their titres, we established that, using a convenient threshold, these antibodies allow $43.2 \%$ of RA to be diagnosed with a specificity of $99 \%{ }^{31}$ Moreover, these antibodies have been linked to the severity and/or the activity of RA but not to disease duration. ${ }^{2124253031}$ Lastly, they were found recently to occur early, ${ }^{34}$ indeed even to precede ${ }^{35}$ the clinical manifestations of RA.

In the absence of any biochemical characterisation of the antigen(s) they recognised, these antibodies were called 'antikeratin antibodies' ('AKA'), probably because the cytokeratins constitute the major protein component of the stratum corneum of cornified epithelia. Previous results, ${ }^{29}$ obtained by the simultaneous IIF assay of a series of RA serum samples both on rat oesophagus epithelium and on human epidermis, suggested that 'AKA' are genuine autoantibodies since the antigen(s) they recognise is also present in the stratum corneum of human epidermis. Using an enzyme-linked immunosorbent assay (ELISA) specific for the detection of antibodies to human epidermal cytokeratins, ${ }^{36}$ we also showed that 'AKA' differ from the natural autoantibodies to these proteins. ${ }^{32}$ Moreover, the antigenic proteins from rat oesophagus epithelium and from human epidermis recognised by the 'AKA' were recently biochemically characterised in our laboratory. The rat oesophagus antigens correspond to three non-cytokeratin late differentiation

31059 Toulouse Cedex

Accepted for publication 22 June 1994 
proteins which had not been previously described and could be related to (pro)filaggrin. ${ }^{37}$ The human epidermis antigens were identified as basic filaggrin and as a new neutral/acidic isoform of this protein. ${ }^{38}$

For a few years, the development of immunoblotting assays has been expanding in various diagnostic fields such as virology and autoimmunity. Such a technique was for example, recently developed for the screening of serum autoantibodies specific for systemic sclerosis (anti-Scl-70) and for polymyositis (anti-Jo1). ${ }^{39}$ Because of its high diagnostic specificity, immunoblotting is also often used as a confirming test after antibody detection by screening test such as ELISA ${ }^{40}$ or IIF. To date, the only method described to detect 'AKA' was IIF on cryosections of rat oesophagus. In spite of its high diagnostic value, this detection was only performed in a few hospital laboratories essentially because of the specific equipment required and of the difficulties of standardisation inherent in such a method.

In the present work, we developed an immunoblotting assay for the detection of 'AKA' using the three protein antigens from rat oesophagus epithelium separated by nondenaturing polyacrylamide gel electrophoresis (PAGE). We assessed the diagnostic sensitivity and specificity of the assay with a series of patients including $88 \mathrm{RA}$ and 100 patients with other non-rheumatoid rheumatic diseases and compared its performance with that of the standard IIF detection of 'AKA' and of the ELISA detection of IgM-RF.

\section{Materials and methods}

SERUM SAMPLES

The serum samples used in this study were obtained from 88 patients with RA following the criteria of the American Rheumatism Association ${ }^{16}$ and from 100 patients with nonRA rheumatic diseases (control serum samples) including 35 patients with various inflammatory rheumatic diseases (six systemic lupus erythematosus, eight psoriatic arthritis, nine ankylosing spondylitis, five gout, and seven miscellaneous connective tissue diseases) and 65 patients with non-inflammatory rheumatic diseases (14 Paget's disease, eight Sudeck's atrophy, four benign gammapathy, five multiple myeloma, 11 various bone diseases, and 23 arthrosis or compressive neuralgia). This sample of patients was representative, in terms of 'AKA' titre distribution, of a larger previously published group of 528 patients with perfectly characterised rheumatic diseases, including 178 patients with RA, 135 patients with non$\mathrm{RA}$ inflammatory rheumatic diseases and 215 patients with non-inflammatory rheumatic diseases. ${ }^{31}$ The serum samples were aliquoted and stored at $-80^{\circ} \mathrm{C}$ until assayed.

INDIRECT IMMUNOFLUORESCENCE

For each serum sample, the titre of IgG 'AKA' was determined by a previously described semiquantitative IIF method. ${ }^{29}{ }^{31}$ Briefly, the fluorescence intensity of the stratum corneum of rat oesophagus epithelium was evaluated on an arbitrary semiquantitative scale from 0 to 4 $(0.25$ unit steps) by two readers uninformed of the clinical context. The results were summed to obtain a titre-like value ranging from 0 to 8 . We previously showed ${ }^{31}$ that a threshold of two on this scale, allowed a diagnostic sensitivity of $43.2 \%$ and a specificity of $99 \%$ to be reached. This threshold was considered as significant for the presence of IgG 'AKA'.

POLYACRYLAMIDE GEL ELECTROPHORESIS (PAGE) AND IMMUNOBLOT TING

Proteins were extracted from rat oesophagus epithelium as previously described. ${ }^{37}$

\section{Electrophoresis}

One dimensional sodium dodecyl sulphate (SDS)-PAGE or non-denaturing (native)PAGE and two dimensional isoelectrofocusing (IEF)/SDS-PAGE or IEF/native-PAGE were performed as previously described ${ }^{37}$ with a PhastSystem $^{\text {TM }}$ (Pharmacia-LKB, Uppsala, Sweden) using $7 \cdot 5 \%$ homogeneous or $8-25 \%$ gradient PhastGels for SDS-PAGE, $8-25 \%$ gradient PhastGels for native-PAGE and PhastGels with ampholytes generating a 5-8 $\mathrm{pH}$ gradient for IEF. Rat oesophagus epithelium extracts were concentrated by precipitation with $10 \%$ trichloroacetic acid for 15 minutes at $0^{\circ} \mathrm{C}$. For SDS-PAGE, the precipitate was dissolved in $10 \mathrm{mmol} / \mathrm{l}$ Tris$\mathrm{HCl}, \mathrm{pH} 7 \cdot 4,2 \%$ SDS, $0 \cdot 01 \%$ bromophenol blue and 1\% 2-mercaptoethanol, and boiled for five minutes. For native-PAGE and IEF, the precipitate was dissolved in distilled water with $0.01 \%$ bromophenol blue. For nativePAGE the following proteins (PharmaciaLKB) were used as markers: horse spleen ferritin $(440 \mathrm{kDa})$, beef liver catalase $(232$ $\mathrm{kDa})$, beef heart lactate dehydrogenase (140 $\mathrm{kDa})$ and bovine serum albumin $(67 \mathrm{kDa})$.

\section{Immunoblotting}

After electrophoretic separation, the epithelium extracts were electrotransferred onto $0.2 \mu \mathrm{m}$ pore size nitrocellulose membranes (Bio-Rad laboratories, Richmond, CA) for one hour at $60 \mathrm{~V}$ in $25 \mathrm{mmol} / \mathrm{l}$ Tris-base, 192 $\mathrm{mmol} / \mathrm{l}$ glycine $\mathrm{pH} 8.3$ containing $20 \%(\mathrm{v} / \mathrm{v})$ methanol. The membranes were cut into vertical strips and blocked for 30 minutes at room temperature with $8.5 \mathrm{mmol} / 1 \quad \mathrm{KH}_{2} /$ $\mathrm{K}_{2} \mathrm{HPO}_{4}, 150 \mathrm{mmol} / \mathrm{l} \mathrm{NaCl}, \mathrm{pH} 7 \cdot 4$, containing $0.05 \%$ Tween-20 (working buffer). Then the strips were incubated for one hour at $37^{\circ} \mathrm{C}$ plus over night at $4^{\circ} \mathrm{C}$ with serum samples diluted to 1:10 in working buffer. After three washing steps in working buffer, the strips were treated for 90 minutes at room temperature with peroxidase-conjugated goat antibodies to human heavy chain $G$ immunoglobulins (Southern Biotech Inc, Birmingham, AL) diluted to $1: 400$ in working buffer. After three washes in working buffer and two washes in $10 \mathrm{mmol} / \mathrm{l}$ Tris- $\mathrm{HCl}, 500 \mathrm{mmol} / \mathrm{l} \mathrm{NaCl}, \mathrm{pH}$ 7.5 , the colour reaction was developed by incubation with peroxidase substrates: $0.5 \mathrm{mg} /$ 
ml 4-chloro-1-naphthol (Bio-Rad), 0.025\% $(\mathrm{v} / \mathrm{v})$ hydrogen peroxide, $17 \%$ methanol $(\mathrm{v} / \mathrm{v})$ in the latter Tris buffer. A negative control, using working buffer without serum, was always included.

Similar to the fluorescence intensity in IIF, the intensity of labelling of each immunoreactive band was estimated by two readers uninformed of the clinical context, according to a semiquantitative scale ranging from 0 to 4 , and the results of the two readers were summed. In previous experiments, such semiquantitative data were found to be strongly correlated $(r=0.97)$ to quantitative estimations obtained with the use of a densitometer (model GS-670, Bio-Rad laboratories). To correct inter-assay variations, which arose mainly from the use of series of antigencoated nitrocellulose membranes, a pool of highly positive RA serum samples was diluted to $1: 400$ and to $1: 3200$ and tested with two strips of each membrane. For each membrane, the estimated values of the labelling intensities of the $A, B$ and $C$ proteins obtained with the two dilutions of the pool were summed. A correction coefficient was then computed for each membrane according to the formula: average of the sums obtained with the whole series of membranes/sum obtained for the given membrane. The correction coefficients ranged between 0.72 and $1 \cdot 63$. All the semiquantitative evaluations performed after assay of the serum samples on the other strips of each membrane were then corrected by the related coefficient. All the serum samples were tested in duplicate on strips from different membranes and the results presented here correspond to the average values of the two assays, which we call titre-like values.

The semiquantitative evaluation of the reactivity to each of the three bands having been performed using three independent scales, the titre-like values of the antibodies to each protein could not be compared in a given serum sample, but allowed the reactivity to a given protein to be compared between the various serum samples.

\section{RHEUMATOID FACTOR}

IgM-RF was determined by ELISA using the Autostat ${ }^{\mathrm{TM}}$ IgM Rheumatoid Factor kit, as described by Cogent Diagnostics Ltd (Edinburgh, United Kingdom).

RF was absorbed from sera on IgG-agarose prepared using highly purified human IgGs (Sigma Chemical Co, St Louis, MO). Each RA serum $(100-150 \mu \mathrm{l})$ was diluted in three volumes of PBS and run three times through a $200 \mu \mathrm{l}$ packed-resin column. The exact volume of the pooled flow-through fractions $(600-800 \mu \mathrm{l})$ was measured to correct the dilution factor in the subsequent immunoblotting experiments. IgM-RF was determined before and after absorption, as described above.

To affinity-purify $R F$, the resin from different columns was packed. After extensive washing, RF was eluted with $0.2 \mathrm{~mol} / 1$ glycine$\mathrm{HCl}, \mathrm{pH} 2.5$ and immediately neutralised by the addition of 0.05 volumes of $2 \mathrm{~mol} / \mathrm{l}$ Tris base.
To test the effect of RF (about $400 \mathrm{IU} / \mathrm{ml}$ ) on the 'AKA' reactivity, $50 \mu \mathrm{l}$ of various sera were diluted to $1: 10$ in $200 \mu$ l of the affinitypurified RF solution (or neutralised elution buffer) and $250 \mu$ l of working buffer, and analysed by immunoblotting as described above.

STATISTIC.AL ANALYSES

Median differences were tested with the MannWhitney U-test, correlations were sought by computing Spearman's rank correlation coefficient and the $\chi^{2}$ test was used to compare percentages. The diagnostic value of 'AKA' detection by immunoblotting was assessed by computing the diagnostic sensitivity $=\mathrm{TP} /$ $(\mathrm{TP}+\mathrm{FN})$ and specificity $=\mathrm{TN} /(\mathrm{TN}+\mathrm{FP})$, in which true positives (TP) were RA patients with a positive test, false positives (FP) were controls with a positive test, true negatives (TN) were controls with a negative test and false negatives (FN) were RA patients with a negative test. Both the diagnostic indexes are given as percentages with $5 \%$ confidence interval.

\section{Results}

ELECTROPHORETIC SEPARATION OF THE RAT OESOPHAGUS EPITHELIUM PROTEINS DETECTED BY 'AKA'

After separation of the epithelial extracts by SDS-PAGE (fig 1A), the specific immunoblotting reactivity of RA serum samples was resolved into two proteinase $\mathrm{K}$-sensitive antigens: a rather sharp band of $210 \mathrm{kDa}$ and a $130-90 \mathrm{kDa}$ smear (spreading down to 60 $\mathrm{kDa}$ with the highly reactive serum samples). After native-PAGE separation of the extract (fig 1B), the RA serum samples reacted with three clearly resolved proteins: a sharp band migrating like a $440 \mathrm{kDa}$ marker, a broader band migrating like a $232 \mathrm{kDa}$ marker and a more diffuse band migrating between a 140 $\mathrm{kDa}$ and a $67 \mathrm{kDa}$ marker, respectively referred to as $\mathrm{A}, \mathrm{B}$ and $\mathrm{C}$ proteins. As shown in previous work wherein native/SDS two dimensional electrophoresis was used, ${ }^{37}$ the antigenic system is actually composed of three distinct proteins: a $210 \mathrm{kDa}$ protein with a $\mathrm{pI}$ ranging from 6 to $7 \cdot 2$ (5.8 to 8.5 with high titred serum samples)-the A protein; a second protein of 90-120 kDa with a similar range of $\mathrm{pI}$ - the $\mathrm{B}$ protein; and a third comma-shaped protein with a pI ranging from 4.5 to 7.2 while its apparent molecular mass ranged from 130 to $60 \mathrm{kDa}$ - the $\mathrm{C}$ protein. These proteins can be separated by IEF/SDS (fig 1C) or IEF/native (fig 1D) two dimensional gel electrophoreses. Because of their partially overlapping apparent molecular mass ranges, $B$ and $C$ proteins were not separated by monodimensional SDSPAGE. Native-PAGE was thus the only one dimensional electrophoresis method allowing the reactivities towards the three antigenic proteins to be independently assessed. This method was therefore chosen to evaluate the immunoblotting reactivities of $88 \mathrm{RA}$ and 100 control serum samples. 
A

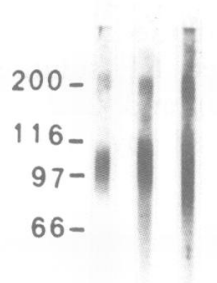

123

\section{B}

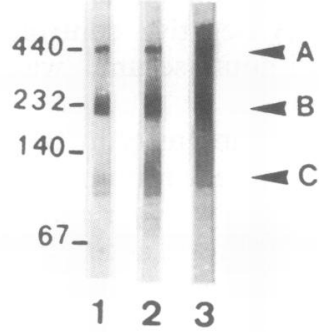

C

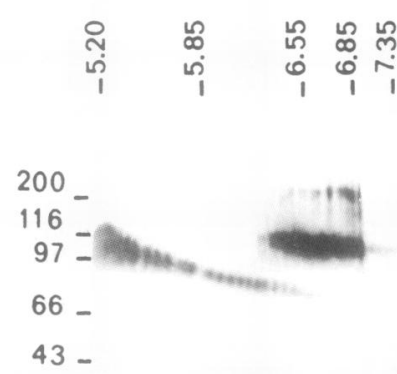

\section{IEF}

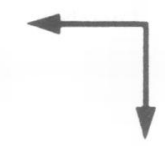

SDS-PAGE
D

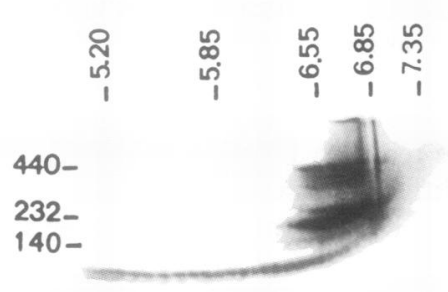

67.

Figure 1 Immunoblotting performed with $R A$ serum samples on rat oesophagus epithelium extract. Protein separated by SDS-PAGE $(A)$ or native-PAGE $(B)$ were electrotransferred onto nitrocellulose membranes then immunodetected with three $R A$ serum samples showing increasing titre-like values for ' $A K A$ ' (1-3). Whatever the electrophoretic conditions, the immunoreactive protein bands were individualised when the serum samples had a low titrelike value for ' $A K A$ ' $(1,2)$, whereas the immunoreactivity extended to the others when the titre-like value for ' $A K A$ ' was greater (3). After SDS-PAGE, two bands are identified, whereas after native-PAGE three bands are seen to be immunoreactive. After IEF/SDS-PAGE (C) or IEF/ native-PAGE (D) two dimensional electrophoreses, the proteins were electrotransferred and immunodetected with an 'AKA'-positive $R A$ serum sample. In both cases, three proteins are visible. After IEF/SDS-PAGE, a first protein of $210 \mathrm{kDa}$ with a pI ranging from 6 to $7 \cdot 2$ (A protein), a second protein of 90-120 kDa with a similar range of $P I$ ( $B$ protein), and a third comma-shaped protein with pI ranging from 4.5 to 7.2 while its apparent molecular mass ranges from 130 to $60 \mathrm{kDa}$ (C protein), can be seen. Migration of protein markers is shown on the left $\left(\mathrm{kDa} \times 10^{-3}\right)$ and of $\mathrm{pI}$ markers at the top of each twodimensional electrophoresis.

ELISA DETERMINATION OF RF

The values of IgM-RF in the RA serum samples ranged from $0 \cdot 1$ to $2159 \mathrm{IU} / \mathrm{ml}$ (median value equal to $199.5 \mathrm{IU} / \mathrm{ml}$ ) whereas those of the control group ranged from 0 to 192 $\mathrm{IU} / \mathrm{ml}$ (median value equal to $4 \mathrm{IU} / \mathrm{ml}$ ). Seventy seven of the $88 \mathrm{RA}$ serum samples $(87.5 \%)$ and 17 of the 100 control serum samples $(17 \%)$ presented IgM-RF values $\geqslant 40$
$\mathrm{IU} / \mathrm{ml}$, the positivity threshold recommended by the manufacturer.

IMMUNOFLUORESCENCE ON RAT OESOPHAGUS CRYOSECTIONS

Eighty seven of the $88 \mathrm{RA}$ serum samples $(98.9 \%)$ and 90 of the 100 control serum samples contained antibodies labelling the stratum corneum of the rat oesophagus epithelium by IIF. The titre-like value of the RA serum samples ranged from 0.00 to 7.25 and that of the control serum samples, from 0.00 to $2 \cdot 25$. Thirty seven of the $88 \mathrm{RA}$ serum samples $(42 \%)$ and only one of the 100 control serum samples showed significant titre-like values of 'AKA' $(\geqslant 2)$.

IMMUNOBLOTTING ON THE RAT OESOPHAGUS EPITHELIUM PROTEINS SEPARATED BY NATIVEPAGE

Patterns of labelling and semiquantitative titrelike values

Antibodies against at least one of the three rat oesophagus proteins were found in 185 of the $188(98.4 \%)$ serum samples. Eighty six $(97 \cdot 7 \%), 88(100 \%)$ and $72(81 \cdot 8 \%)$ of the 88 RA serum samples were found to be reactive to the $\mathrm{A}, \mathrm{B}$ and $\mathrm{C}$ proteins, respectively. Conversely, 67, 96 and only six of the 100 control serum samples were found to be reactive to the same proteins, respectively. Figure 2 illustrates the reactivity of a representative subset of serum samples.

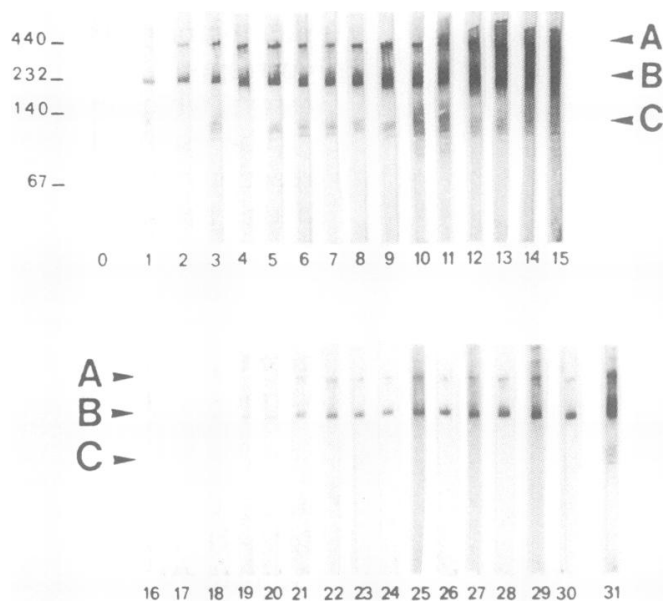

Figure 2 Patterns of reactivity of $R A$ and control serum samples assayed by immunoblotting on rat oesophagus epithelium extract. After native-PAGE separation and electrotransfer of the extract, the strips of nitrocellulose membrane were incubated without serum (0) or with serum samples (1-31). Fifteen $R A(1-15)$ and 16 control (16-31) serum samples, representative of the groups of $R A$ and controls, respectively, are illustrated. The serum samples are classified according to the increasing immunoreactivity to the $B$ protein. Among the $15 R A$ serum samples, only one reacts with the $B$ protein alone (1), two of them are positive with only the $A$ and $B$ proteins (2, 4) whereas the others react with the three proteins $A, B$ and $C(3,5-15)$. The serum samples with high titre-like values of ' $A K A$ ' react with the three proteins according to a continuous pattern which extends from the $A$ to the $C$ protein $(14,15)$. With the control serum samples, no reactivity (16), reactivity to the $B$ protein alone (17-20) or reactivity to the $A$ and $B$ proteins (21-30) is found. Only one control serum sample is positive with the $A, B$ and $C$ proteins (31). Migration of protein markers is shown on the left $\left(\times 10^{-3}\right)$ and the positions of the three proteins, referred to as $A, B$ and $C$, is noted. 
Patterns of immunoblotting labelling produced by the $R A$ and the control serum samples on the rat oesophagus epithelium antigens ( $A, B$ and $C$ proteins) separated by native-PAGE

\begin{tabular}{lllll}
\hline$A$ & $B$ & $C$ & $88 R A$ & 100 controls \\
\hline- & - & - & 0 & 3 \\
- & - & $\times$ & 0 & 0 \\
$\overline{\times}$ & $\times$ & - & $2(2 \cdot 3 \%)$ & 29 \\
$\times$ & - & - & 0 & 1 \\
$\times$ & $\times$ & - & $14(15 \cdot 9 \%)$ & 61 \\
- & $\times$ & $\times$ & 0 & 0 \\
$\times$ & $\times$ & $\times$ & 0 & 1 \\
\hline
\end{tabular}

*The serum samples were grouped according to the protein(s) they labelled, whatever the intensity of labelling. The labelling of each protein was noted with an ' $X$ ' in the relevant column and was taken as positive when it had been considered to be present by each of the two readers in each of the two assays.

Among the eight different patterns of labelling that could theoretically be defined combining the presence or absence of labelling of each band, six were actually observed, among which three were produced by $97 \cdot 3 \%$ of the serum samples, that is, the labelling of A + B + C, of A + B or of B alone. The whole analysis is presented in the table. A large majority $(81 \cdot 8 \%)$ of the RA serum samples simultaneously recognised the three proteins. All but one of the RA serum samples that presented significant IIF titre-like values of 'AKA' showed this pattern. In contrast, the three proteins were simultaneously labelled by only five of the 100 control serum samples which mainly labelled both $A$ and $B$ proteins $(61 \%)$ or B protein alone $(29 \%)$.

After semiquantitative evaluation of their reactivity to the three proteins, the RA serum samples ranged all along the titre-like value scale, whatever the considered protein, with median titre-like values of $4 \cdot 22,5 \cdot 05$ and $4 \cdot 80$, for the A, B and C proteins, respectively (fig 3 ). On the other hand, the titre-like values of antibodies in the control serum samples were restricted to the lower part of the scale, since the maximum titre-like values were $4 \cdot 74,5 \cdot 76$ and 2.32 and the median values were 0.51 , 1.16 and 0.00 , for the $A, B$ and $C$ proteins, respectively.
To demonstrate that the differences in the predominant labelling patterns produced by the RA serum samples $(A+B+C)$ and by the control serum samples $(A+B)$ did not result from the lower titre-like values of antibodies in the controls, we analysed the labelling patterns in two subgroups of $30 \mathrm{RA}$ and 30 control serum samples, paired for the titre-like value of antibodies to the $B$ protein. In these subgroups, $17(56.7 \%)$ of the RA serum samples and only one $(3 \cdot 3 \%)$ of the control serum samples produced the pattern A + B + C, while $10(33.3 \%)$ of the RA serum samples and $26(86 \cdot 7 \%)$ of the control serum samples produced the pattern $\mathrm{A}+\mathrm{B}$ $(p<0.001)$. The remaining serum samples (three in each subgroup) showed the pattern B alone.

In the control serum samples, the titre-like values for antibodies labelling the $\mathrm{B}$ protein alone (median $=0.56$ ) were significantly lower than the titre-like values for antibodies labelling $\mathrm{B}$ protein in the $\mathrm{A}+\mathrm{B}$ pattern subgroup (median titre-like value 1.50 ) (p $\ll 0.0001$ ). The very strong correlation we found between the titres of antibodies labelling the $A$ protein and those of the antibodies labelling the $B$ protein being taken into account (see below), it was seen that the shift from the pattern $B$ alone to the pattern $A+B$ only depended on the increase of the antibody titre.

\section{Diagnostic indexes}

The diagnostic sensitivity and specificity were computed from the distribution of the RA and the control serum samples at each step of the semiquantitative scale separately for each protein. The resulting curves (fig 3 ) showed that the detection of antibodies to the $\mathrm{A}$ and B proteins presented comparable sensitivity and specificity for the diagnosis of RA. However, at a threshold corresponding to the first step of the semiquantitative scale $(0 \cdot 25)$, the specificity of the detection of antibodies to the C protein reached $94 \%(89 \cdot 3 \%-98 \cdot 7 \%)$

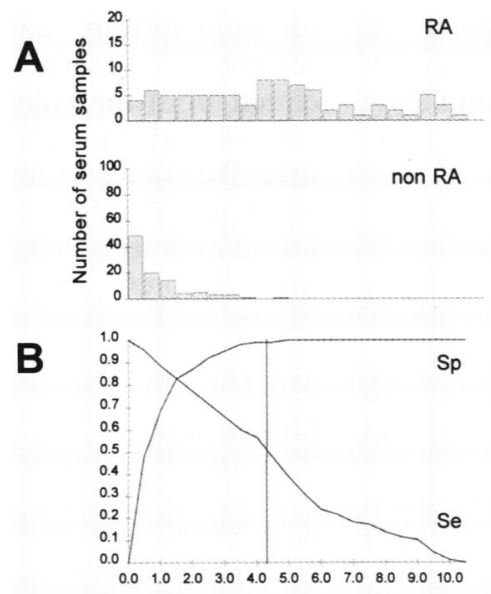

A protein

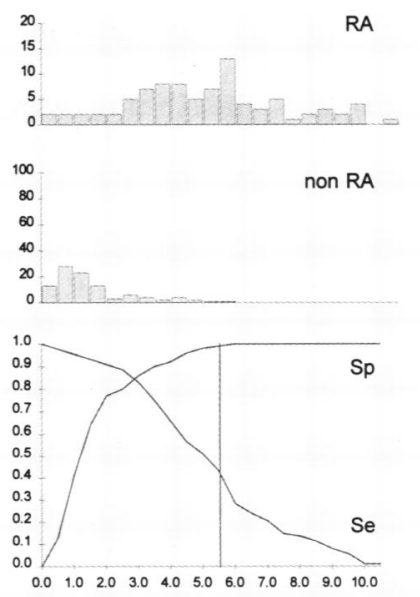

B protein
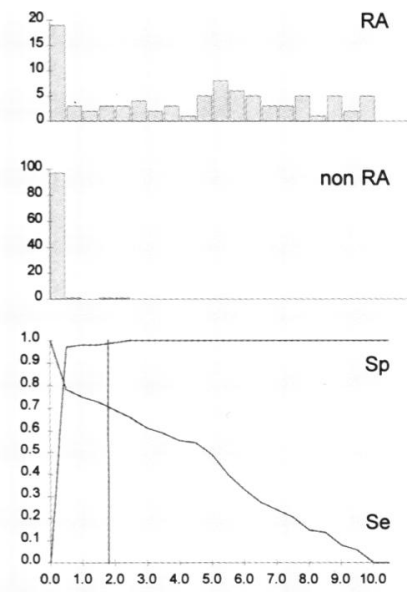

C protein

Figure 3 Distribution of immunoblotting titre-like values $(A)$ and diagnostic indexes $(B)$ of antibodies to the $A, B$ and $C$ proteins. (A) The distributions are shown for $R A$ and non- $R A$ patients for each level of the semi-quantitative scale of immunoblotting titre-like values. (B) The diagnostic sensitivity ( $S e$ ) and specificity (Sp) for $R A$ of the detection of the antibodies to the three proteins were computed from the distributions above. Vertical lines show the thresholds of labelling intensity which correspond to a diagnostic specificity of $99 \%(0.99)$. 
while the specificities were only $32 \%$ $(22 \cdot 8 \%-41 \cdot 2 \%)$ and $4 \%(0 \cdot 1 \%-7 \cdot 9 \%)$ for the detection of antibodies to the $\mathrm{A}$ and $\mathrm{B}$ proteins, respectively. At a chosen specificity of $99 \%$, the diagnostic sensitivities of the detection of antibodies to the $\mathrm{A}$ and to the $\mathrm{B}$ proteins were $50 \%(39 \cdot 6 \%-60.4 \%)$ and $43 \cdot 2(32 \cdot 8 \%$ $53.6 \%)$, respectively. These sensitivities did not significantly differ from each other or from the diagnostic sensitivity of the detection of 'AKA' by IIF which was $42 \%(31 \cdot 6 \%-52 \cdot 4 \%)$. In contrast, the diagnostic sensitivity of the detection of antibodies to the $\mathrm{C}$ protein was $70 \cdot 5 \%(60 \cdot 9 \%-80 \cdot 1 \%)$ and was found to be significantly higher than all the above cited sensitivities $(p<0 \cdot 01)$. Moreover, the latter diagnostic sensitivity was also found to be significantly higher than the diagnostic sensitivity of the detection of IgM-RF by ELISA that was $54.5 \%(43.9 \%-65 \cdot 1 \%)$, at a threshold of $191 \mathrm{IU} / \mathrm{ml}$ chosen to get the same specificity of $99 \%(p=0 \cdot 04)$.

STATISTICAL AND IMMUNOCHEMICAL

RELATIONSHIPS BETWEEN THE VARIOUS

ANTIBODIES STUDIED

The relationships between the IgM-RF determined by ELISA, the titres of antibodies to the stratum corneum of rat oesophagus epithelium detected by IIF and those of the antibodies to the $\mathrm{A}, \mathrm{B}$ and $\mathrm{C}$ proteins detected by immunoblotting, were sought separately in the RA and in the control serum samples.

In the group of RA patients, the titres of antibodies to the $\mathrm{A}$ and to the $\mathrm{B}$ proteins, to the $B$ and to the $C$ proteins, and to the $A$ and to the $C$ proteins were found to be strictly correlated $(r=0.97,0.83$ and 0.79 , respectively, with $p \ll 0.0001)$. In the group of control patients, the antibodies to the $\mathrm{A}$ and to the $\mathrm{B}$ proteins were also found to be strongly correlated $(\mathrm{r}=0.96, \mathrm{p} \ll 0.0001)$ but varied independently of the antibodies to the $C$ protein.

In the group of RA patients, the antibodies to the $A, B$ and $C$ proteins were found to be correlated with the titres of 'AKA' detected by IIF ( $r=0.53,0.53$ and 0.56 , respectively, with $\mathrm{p} \ll 0.0001)$, while, in the group of control patients, the IIF titres were found to be independent of the antibody titres to the three proteins.

In the group of RA patients, the titres of 'AKA' detected by IIF were found to be correlated with the IgM-RF detected by ELISA ( $r=0.31$, with $\mathrm{p}<0.01$ ), as generally observed. In this group, the antibodies to the $A, B$ and $C$ proteins were also found to be correlated with the IgM-RF $(r=0.34,0.37$ and 0.36 , respectively, with $\mathrm{p}<0.001)$. In the group of control patients, the IgM-RF values were found to be independent of the other detected antibodies.

In the subset of RA patients with titre-like values of antibodies to the $\mathrm{C}$ protein $<1 \cdot 75$, $35 \%(9 / 26)$ were RF-positive at the specificity threshold of $99 \%$ ( $\geqslant 191 \mathrm{IU} / \mathrm{ml})$. In particular, two of the latter sera did not react with the $C$ protein at all. Similarly, in the subset of RA

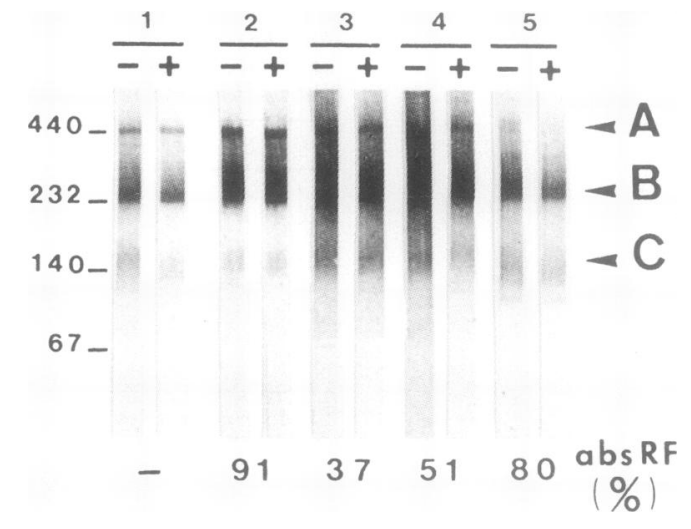

Figure 4 Reactivity of $R F$-absorbed $R A$ serum samples assayed by immunoblotting on rat oesophagus epithelium extract. An $R A$ serum sample (1) with a low value of $R F$ (3 IU/ml) and four $R A$ serum samples (2-5) with high values of $R F(1089,840,1478$ and $1061 \mathrm{IU} / \mathrm{ml}$, respectively) were absorbed onto IgG-agarose columns. Percentages of absorbed IgM-RF (abs RF) were determined by ELISA. RA serum samples were analysed by immunoblotting as in fig 2 before $(-)$ and after ( + ) absorption. Reactivities to the $A, B$ and $C$ proteins were not modified.

patients with titre-like values of antibodies to the $\mathrm{C}$ protein $\geqslant 1 \cdot 75,37 \%(23 / 62)$ were $\mathrm{RF}$ negative $(<191 \mathrm{IU} / \mathrm{ml})$. In particular, two sera with $R F \leqslant 3 \mathrm{IU} / \mathrm{ml}$ reacted with the $C$ protein with high titre-like values $>5$. In the subset of RF-negative patients, 35\% (14/40) were 'AKA'-positive and 58\% (23/40) presented a titre-like value of antibodies to the $\mathrm{C}$ protein $\geqslant 1 \cdot 75$. These data clearly indicate that antibodies to the $\mathrm{C}$ protein and RF are distinct from each other.

We further evaluated the immunological relationship between RF (all isotypes) and antibodies to the $\mathrm{C}$ protein, in particular an eventual cross-reaction of $R F$ with the protein and an eventual RF-induced amplification of immunoblotting reactivity. With this aim, four serum samples with a high value of $\mathrm{RF}$ (>839 IU/ml) were run through columns of human IgG coupled to agarose. By this means, up to $91 \%$ and at least $37 \%$ of IgM-RF was absorbed. When the absorbed and unabsorbed serum samples were compared by immunoblotting analysis, no modification of reactivity was seen (fig 4 ). In addition, $R F$ eluted from the columns, were added in two control and one RA serum samples with low titre-like values of antibody to the $\mathrm{C}$ protein. As expected if $\mathrm{RF}$ does not interfere with the immunoblotting assay, the low reactivities to the $\mathrm{C}$ protein were not modified (data not shown).

\section{Discussion}

The immunoblotting assay we present here is the first immunochemical method proposed to date for the detection of 'AKA'.

The aim of the study was to obtain a test presenting diagnostic performances equal to or better than those of the standard IIF method. This was achieved because, although all $88 \mathrm{RA}$ serum samples and also 97 of the 100 control serum samples were found to be reactive to at least one of the three protein antigens, the 
reactivity was found to be different in terms of labelling pattern as well as in terms of titre-like values, allowing RA to be diagnosed with a high specificity. We have shown in previous IIF studies $^{2931}$ that, because of the probable presence of low titred non-disease-specific antibodies which label the stratum corneum of rat oesophagus epithelium, the presence of 'AKA' can only be asserted with sufficient specificity when their titre-like value reaches a threshold of 1.5 (95\% specificity) or $2.0(99 \%$ specificity). The immunoblotting detection of 'AKA' followed the same rule since the detection of antibodies to the $\mathrm{A}$ and to the $\mathrm{B}$ protein required the choice of a convenient threshold (4.25 and 5.50, respectively), to reach a specificity of $99 \%$ for RA. At these thresholds, the sensitivity was similar to that of IIF 'AKA' detection (near 45\%). The detection of the antibodies to the $\mathrm{C}$ protein allowed the same specificity to be obtained at a threshold of $1 \cdot 75$. At this threshold, the diagnostic sensitivity of the detection of antibodies to the $\mathrm{C}$ protein $(70.5 \%)$ was significantly higher than those of the antibodies to the $A$ and $B$ proteins as well as that of the detection of 'AKA' by IIF. For diagnostic purposes therefore the antibodies to the $C$ protein could be considered alone, whatever the labelling of the other protein antigens. The mere presence of these antibodies, whatever their titre-like value, allowed $81 \cdot 8 \%( \pm 8 \%)$ of RA to be diagnosed with a specificity of $94 \%$ $( \pm 2 \cdot 3 \%)$.

The analysis of the labelling patterns showed that a large majority of the RA serum samples labelled the three proteins $(A+B+C)$ simultaneously. In the RA serum samples, the titres of the antibodies that labelled the three proteins were found to be strongly correlated with each other and also correlated with the titres of 'AKA', detected by IIF. The values of the correlation coefficients favour the hypothesis that the antibodies detected on the three proteins are largely the same and that the epitopes recognised by 'AKA' on the stratum corneum of rat oesophagus epithelium are shared by the three protein antigens detected by immunoblotting.

Of the reactive control serum samples, $95 \%$ labelled either the A and B proteins or the B protein alone. The idea that the antibodies which label the A and the B protein in the control serum samples are identical, was supported by the close correlation we found between their titre-like values, the labelling of the $B$ protein alone not being a pattern distinct from $A+B$, but only resulting from the low titre of the antibodies. In addition, we showed that the near-absence of labelling of the $C$ protein by the control serum samples did not result from their lower median titre-like value with regard to the RA serum samples, but indicated the actual absence of antibodies to the $\mathrm{C}$ protein. As a whole, these results showed the presence, in the serum samples from patients with non-RA rheumatic diseases, of non-disease-specific antibodies recognising epitopes shared by the A and B proteins but absent from the $\mathrm{C}$ protein.
The existence of at least two independent antibody families distinguishable by their labelling pattern $(A+B+C$ : specific for $R A$; $A+B$ : non-disease specific) can be used as a criterion for immunoblotting interpretation. Indeed, the classification of the serum samples according to their labelling pattern allowed RA to be diagnosed with a specificity of $95 \%$ (only five false positives) and a sensitivity of $81.8 \%$ (table), these diagnostic indexes being similar to those of the detection of antibodies to the $\mathrm{C}$ protein at a threshold of $0 \cdot 25$.

The association between RF and 'AKA', detected by IIF or by the immunoblotting assay we developed, is closed. However, it seems unlikely that a cross-reaction exists between $\mathrm{RF}$ and 'AKA' for the following reasons: (1) Whereas RA-specific 'AKA' are exclusively IgG, $R F$ are mainly of the $M$ isotype. (2) It is well known that 'AKA' occur in RF-negative RA. In the same way, we also detected immunoblotting activities to the $\mathrm{C}$ protein in IgM-RF-negative RA. Moreover, some 'AKA'-positive serum samples have been described as completely negative for IgG-RF ${ }^{35}$. (3) Absorption of 'AKA'-positive serum samples with aggregated human IgG, to remove RF, did not abolish 'AKA' activity. ${ }^{18}$ Similarly, absorption of the samples on agarose-coupled IgG did not modify their immunoblotting activity toward the three proteins of rat oesophagus epithelium. (4) The addition of affinity-purified RF to RA sera did not modify their immunoblotting reactivity.

Besides 'AKA', another powerful diagnosis marker antibody, the antiperinuclear factor, has been described in RA serum samples. ${ }^{33}$ Since 'AKA' react with filaggrin in the cornified cells of human epidermis ${ }^{38}$ and the antiperinuclear factor reacts with superficial cells of human buccal epithelium (two squamous epithelia), the two antibodies could possibly be related. The antigen recognised by the antiperinuclear factor needs to be purified and characterised to highlight the exact relationship between both the RA-specific antibodies.

In conclusion, the previous isolation and characterisation of the rat oesophagus epithelium antigens recognised by the so-called 'AKA', allowed us to develop an original immunoblotting assay for the diagnosis of RA. The analysis of the immunoblotting labelling patterns showed that the RA-specific antibodies recognised epitope(s) shared by the three protein antigens, while non-RA-specific antibodies found in control patients reacted with epitope(s) shared by only two of the three proteins. Even if determined on a sample of 188 patients representative of a larger sample of 528 patients, the diagnostic performances of the immunoblotting assay should be validated on larger series of patients, particularly patients with systemic lupus erythematosus, systemic sclerosis and other connective tissue diseases, but also other types of chronic arthritides. However the performances already seem to be clearly better than those of the IIF detection of 'AKA'. Moreover, if a commercially marketed kit is developed on the basis of these results, 
it will be easier to use by clinical laboratories than IIF, because of its limited technical requirements.

This immunoblotting assay should rapidly be confirmed as the most effective method for the serological diagnosis of RA.

We are very grateful to Professor $F$ Amalric (Institut de Biologie Cellulaire et de Génétique, CNRS, Toulouse) and to Dr G Sommé (Société Clonatec, Paris) for their useful advice and to M-F Isaia, M-P Rué and B Pianezzi for their excellent technical assistance. Supported in part by grants from Clonatec, technical assistance. Supported in part by grants from Clonatec, Fondation pour la Recherche Médicale, and the Région MidiPyrénées.

1 Waaler E. On the occurrence of a factor in human serum activating the specific agglutination of sheep blood corpuscules. Acta Pathol Microbiol Scand 1940; 17: 172-88.

2 Rose H M, Ragan C, Pearce E, Lipman M O. Differential agglutination of normal and sensitized sheep erythrocytes agglutination of normal and sensitized sheep erythrocytes by serum samples of patients with rh
Proc Soc Exp Biol Med 1948; 68: 1-6.

3 Singer J M, Plotz C M. The latex fixation test. I-Application to the serological diagnosis of rheumatoid arthritis. $A m \mathcal{F}$ Med 1956; 21: 888-96.

4 Nienhuis R L F, Mandema E, Smids C. A new serum factor in patients with rheumatoid arthritis, the antiperinuclear factor. Ann Rheum Dis 1964; 23: 302-5.

5 Menzel J, Steffen C, Kolarz G, Erbel R, Franck O, Thumb $N$. Demonstration of antibodies to collagen and of collagen-anticollagen immune complexes in rheumatoid
arthritis synovial fluid. Ann Rheum Dis 1976; 35: 446-50.

6 Andersen I, Andersen P, Graudal H. Smooth-muscle antibodies in rheumatoid arthritis. Acta Pathol Microbiol antibodies in rheumatoi
Scand 1980; 88: $131-5$.

7 Venables P J W, Roffe L M, Erhardt C C, Maini R N, Edwards J M B, Porter A D. Titers of antibodies to RANA in rheumatoid arthritis and normal sera: relationship to Epstein-Barr virus infection. Arthritis Rheum 1981; 24, 1459-64.

8 Osung O A, Chaudra M, Holborow E J. Antibodies to intermediate filaments of the cytoskeleton in rheumatoid arthritis. Ann Rheum Dis 1982; 41: 69-73.

9 Berstein R M, Hobbs R N, Lea D J, Ward D J, Hughes G R V. Patterns of antihistone antibody specificity in systemic rheumatic diseases. I. Systemic lupus erythematosus, mixed connective tissue diseases, primary sicca syndrome and rheumatoid arthritis with vasculitis. Arthritis Rheum 1985; 28: 285-93.

10 Carson D A. Rheumatoid factor. In: Kelley W N, Harris E D Jr, Ruddy S, Sledge C B, eds. Textbook of E D Jr, Ruddy S, Sledge C B, eds. Textbook of
rheumatology. Philadelphia: W B Saunders, 1989: rheumatolog.

11 Terato K, Shimozuru Y, Katayama K, et al. Specifity of antibodies of type II collagen in rheumatoid arthritis. Arthritis Rheum 1990; 33: 1493-500

12 Lassoued S, Oksman F, Fournié B, Danon F, Fournié A, Lassoued $\mathrm{K}$. Autoantibodies to lamins in rheumatoid arthritis. Arthritis Rheum 1990; 33: 877-9.

13 Petersen J, Rhodes G, Roudier J, Vaughan J H. Altered immune response to glycine-rich sequences of EpsteinBarr nuclear antigen-1 in patients with rheumatoid arthritis and systemic lupus erythematosus. Arthritis Rheum 1990; 33: 993-1000.

14 Hoet R M, Voorsmit R A C A, Van Venrooij W J. The perinuclear factor, a rheumatoid arthritis-specific autoperinuclear factor, a rheumatoid arthritis-specific autoantigen, is not present in keratohyalin granules of cultured

15 Steiner G, Hartmuth K, Skriner K, et al. Purification and partial sequencing of the nuclear autoantigen RA33 shows that it is indistinguishable from the A2 protein of the heterogeneous nuclear ribonucleoprotein complex. $\mathcal{F}$ Clin Invest 1992; 90: 1061-6.

16 Arnett F C, Edworthy S M, Bloch D A, et al. The American Rheumatism Association 1987 revised criteria for the classification of rheumatoid arthritis. Arthritis Rheun 1988; 31: 315-24.

17 Shmerling R H, Delbanco T L. The rheumatoid factor: an analysis of clinical utility. Am f Med 1991; 91: 528-34.

18 Young B J J, Mallya R K, Leslie R D G, Clarck C J M Hamblin T J. Anti-keratin antibodies in rheumatoid arthritis. BMf 1979; 2: 97-9.
19 Johnson G D, Carvalho A, Holborrow E J, Goddard D H, Russell G. Antiperinuclear factor and keratin antibodies in rheumatoid arthritis. Ann Rheum Dis 1981; 40: 263-6.

20 Scott D L, Delamere J P, Jones L J, Walton K W. Significance of laminar antikeratin antibodies to rat oesophagus in rheumatoid arthritis. Ann Rheum Dis 1981; 40: $267-71$.

21 Miossec P, Youinou P, Le Goff P, Moineau M P. Clinical relevance of antikeratin antibodies in rheumatoid arthritis. Clin Rheumatol 1982; 1: 185-9.

22 Mallya R K, Young B J J, Pepys M B, Hamblin T J, Mace B E W, Hamilton E B D. Anti-keratin antibodies in rheumatoid arthritis: frequency and correlation with other features of the disease. Clin Exp Immunol 1983; 51: 17-20.

23 Quismorio F P Jr, Kaufman R L, Beardmore T, Mongan E S. Reactivity of serum antibodies to the keratin layer of rat oesophagus in patients with rheumatoid arthritis. Arthritis Rheum 1983; 26: 494-9.

24 Ordeig J, Guardia J. Diagnostic value of antikeratin antibodies in rheumatoid arthritis. $\mathcal{F}$ Rheumatol 1984; 11 : $602-4$.

25 Hajiroussou V J, Skingle J, Gillett A P, Webley $M$. Significance of antikeratin antibodies in rheumatoid arthritis. F Rheumatol 1985; 12: 57-9.

26 Kataaha P K, Mortazavi-Milani S M, Russell G, Holborrow E J. Anti-intermediate filaments antibodies, antikeratin antibody, and antiperinuclear factor in rheumatoid arthritis and infectious mononucleosis. Ann Rheum Dis arthritis and infecti

27 Youinou P, Le Goff P, Colaco C B, et al. Antikeratin antibodies in serum and synovial fluid show specificity for rheumatoid arthritis in a study of connective tissue diseases. Ann Rheum Dis 1985; 44: 450-4.

28 Meyer O, Fabregas D, Cyna L, Ryckewaert A. Les anticorps anti-kératine: Un marqueur des polyarthrites rhumatoïdes évolutives. Rev Rhum Mal Ostéoartic 1986; 53: 601-5.

29 Serre G, Vincent C, Fournié B, Lapeyre F, Soleilhavoup J-P, Fournié A. Anticorps anti-stratum corneum d'oesophage de rat, auto-anticorps anti-kératines épidermiques et antiépiderme dans la Polyarthrite Rhumatoïde et différentes affections rhumatologiques. Rev Rhum Mal Ostéoartic 1986; 53: 607-14.

30 Kirstein H, Mathiesen F K. Antikeratin antibodies in rheumatoid arthritis. Scand $\mathcal{f}$ Rheumatol 1987; 16: 331-7.

31 Vincent C, Serre G, Lapeyre F, et al. High diagnostic value in rheumatoid arthritis of antibodies to the stratum corneum of rat oesophagus epithelium, so-called 'antikeratin antibodies'. Ann Rheum Dis 1989; 48: 712-22

32 Vincent C, Serre G, Fournié B, Fournié A, Soleilhavoup J-P. Natural IgG to epidermal cytokeratins vs IgG to the stratum corneum of the rat oesophagus epithelium, socalled 'antikeratin antibodies', in rheumatoid arthritis and other rheumatic diseases. If Autoimmun 1991; 4: 493-505.

33 Hoet R M, Van Venrooij W J. The antiperinuclear factor (APF) and antikeratin antibodies (AKA) in rheumatoid arthritis. In: Smolen J S, Kalden J R, Maini R N, eds. arthritis. In: Smolen J S, Kalden J R, Maini R N, eds. Rheumatoid arthritis
1992: 299-318.

34 Paimela L, Gripenberg $M$, Kurki P, Leirisalo-Repo $M$. Antikeratin antibodies: diagnostic and prognostic markers for early rheumatoid arthritis. Ann Rheum Dis 1992; 51: 743-6.

35 Kurki P, Aho K, Palosuo T, Heliövaara M. Immunopathology of rheumatoid arthritis: Antikeratin antibodies precede the clinical disease. Arthritis Rheum 1992; 35: 914-7.

36 Serre G, Vincent C, Viraben R, Soleilhavoup J-P. Natural IgM and IgG autoantibodies to epidermal keratins in normal human sera. I. ELISA-titration, immunonormal human sera. I. ELISA-titration, immuno

37 Girbal E, Sebbag M, Gomès-Daudrix V, Simon M, Vincent C, Serre G. Characterisation of the rat oesophagus epithelium antigens defined by the so-called 'antikeratin epithelium antigens defined by the so-called 'antikeratin
antibodies', specific for rheumatoid arthritis. Ann Rheum antibodies', specific for

38 Simon M, Girbal E, Sebbag M, et al. The cytokeratin filament-aggregating protein filaggrin is the target of the so-called 'antikeratin antibodies', autoantibodies specific for rheumatoid arthritis. $\mathcal{f}$ Clin Invest 1993; 92: 1387-93.

39 Fonong T, Evans S M, Homburger H A. Development and comparative evaluation of immunoblot assays for detecting autoantibodies to $\mathrm{Scl} 70$ and Jo 1 antigens in serum. Clin Chem 1990; 36: 2053-6.

40 Weber B, Hess G, Enzensberger R, et al. Multicenter evaluation of the novel ABN Western blot (Immunoblot) system in comparison with an enzyme-linked immunosorbent assay and a different Western blot. $\mathcal{F}$ Clin Microbiol 1992; 30: 691-7. 